\title{
Influence of leading edge damage of aircraft engine compressor blades on their fatigue strength
}

\author{
Wpływ uszkodzenia krawędzi natarcia łopatek sprężarki sillnika lotniczego \\ na ich wytrzymałość zmęczeniową
}

\author{
WOJCIECH OBROCKI \\ AMADEUSZ SETKOWICZ \\ MACIEJ MASŁYK \\ JAN SIENIAWSKI *
}

\begin{abstract}
Article presents the research results of the influence of aircraft compressor blade damage length and its position on fatigue strength under high number of cycles conditions. The criteria for blade damage detection classification and test research methodology were developed. The instrumentation for compressor blades fatigue tests was designed and constructed. Fluorescent method was used to determine the fatigue crack initiation sites and its propagation direction during fatigue test.
\end{abstract}

KEYWORDS: aircraft engine, compressor, blade, fatigue tests, fatigue strength

In order to ensure safety in the flight and striving to reduce aircraft operating costs, it is necessary to look for innovative solutions for the control of components and the rotating assembly, especially the critical elements of these constructions. At the same time, the adopted solutions must meet the highest standards of operational safety of aircraft drives [1].

The current tendency to build aircraft engines with high power and efficiency, and definitely lower mass leads to increased loads of individual subassemblies and their components. For example, the compressor's working vanes are more loaded and, at the same time, have a smaller blade thickness and complex shapes of the working surface. In addition, during use, there is intensive erosive wear of the blades and their corrosion caused by operating conditions. Taking into account these factors, the design requirements for compressor blades of aircraft engines meeting high safety criteria are increasingly rigorous [1].

At the turn of the 20th and 21st centuries, progress was made in the theoretical analysis of the gas stream moving in the compressor and turbine components of aircraft engines. Improved models of new engine designs as well as their loads and working conditions have been developed. Modern computational methods have been introduced in numerical

\footnotetext{
* Mgr inż. Wojciech Obrocki, mgr inż. Amadeusz Setkowicz, mgr inż. Maciej Masłyk, prof. dr hab. inż. Jan Sieniawski (jansien@prz.edu.pl) - Department of Materials Science, Faculty of Mechanical Engineering and Aeronautics, Rzeszow University of Technology, Poland
}

simulation processes. Despite the development of numerical simulation methods, however, they do not take into account all the phenomena characteristic of the work of aircraft engine components. Therefore, experimental studies of models and real objects are still of great importance at the design and construction stages as well as the operation of aircraft engine structures. The results of the experiments form the basis for the verification of accepted models. They are also indispensable for identification and theoretical justification of physical phenomena typical for the work of aircraft engines [2].

The analysis of the literature data and the results of own research shows that the majority of failures of aircraft engine compressors are caused by damage to the vanes and their insufficient strength under conditions of permanent and variable loads [3]. It was found that fatigue cracks are the cause of approx. $70 \div 80 \%$ of engine failures. Analysis of the process of initiation and propagation of these cracks confirmed that their main cause are severe working conditions of the blades. Shoulders are, among others exposed to damage by foreign objects [4] - particles with high hardness, most often of mineral origin. They are present in the air sucked into the flow channels of the engine and cause erosive wear of structural elements [5]. Also, larger solid objects, e.g. fragments of airport pavements, cause damage. The blades during operation of the engine are therefore heavily exposed to a foreign object damage (FOD).

Due to the nature of the operation of the blades during their work, the useful properties determined at the design stage of the engine must be maintained. Compressor blades of aircraft engines work under loads causing both low-cycle fatigue (change of rotational speed) and high-cycle fatigue (vibrations of blades, change of gas flow dynamics).

Analysis of the causes of engine failures indicates that in the majority of cases, the fatigue strength of the blade after impact by the foreign objects is reduced. The effect of the plastic deformation of the material in the impact zone is the notch in which the stress concentration takes place and the fatigue strength decreases. It was stated that depending on the value of the FOD impact energy, the initiation and propagation of fatigue crack are of different nature [6]. In addition, the continuous change in the shape of the curved surface of the blade and the change of the cross-sectional area of the blade poses difficulties in determining the degree 
of impact of damage to these elements by solid objects. These issues are still at the center of interest for the constructors of aircraft propulsion [7, 8].

The aim of the undertaken research is an attempt to develop a methodology for assessing the impact of damage to the leading edges of an aircraft engine's compressor blades on their fatigue strength.

\section{Material and methodology of research}

The first stage air compressor vanes were made of martensitic steel with chemical composition: $11 \% \mathrm{Cr} ; 1.6 \%$ $\mathrm{W} ; 1.5 \% \mathrm{Ni} ; 0.35 \% \mathrm{Mo} ; 0.18 \% \mathrm{~V} ; 0.11 \% \mathrm{C} ; 0.03 \% \mathrm{P}$ and $0.025 \%$ S. In order to realize the main objective of the research, the criteria for the classification of blades defects were developed depending on their length and position on the leading edge in relation to the blade lock. Five zones of blade height and eight groups of defects length were identified (fig. 1, fig. 2, tab. I and tab. II) [9].

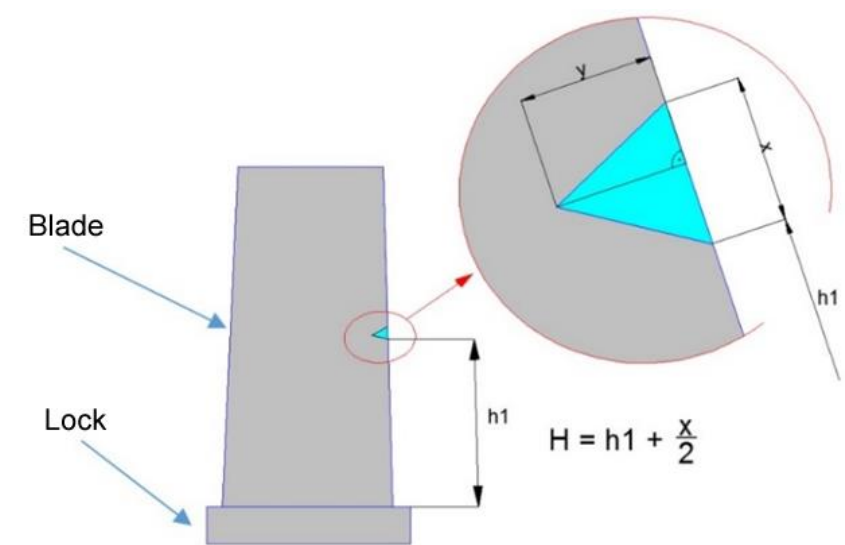

Fig. 1. Scheme of the compressor blade and defect measurement methodology

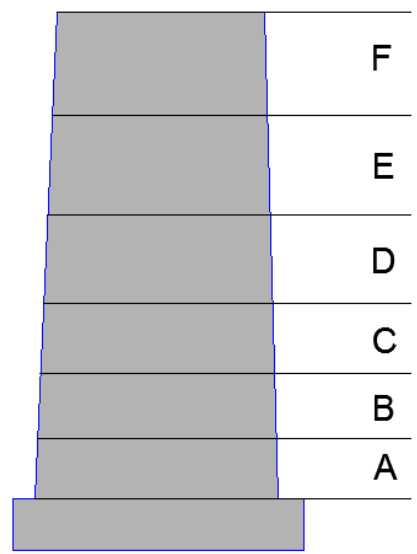

Fig. 2. Zones of the position of the blade defects

TABLE I. Groups of blade defects depending on the length

\begin{tabular}{|c|c|}
\hline Defect group & Defect lenght $y, \mathrm{~mm}$ \\
\hline I & $0 \div 0,099$ \\
\hline II & $0,1 \div 0,199$ \\
\hline III & $0,2 \div 0,299$ \\
\hline IV & $0,3 \div 0,499$ \\
\hline VI & $0,5 \div 0,999$ \\
\hline VII & $1 \div 1,999$ \\
\hline VIII & $2 \div 2,999$ \\
\hline
\end{tabular}

TABLE II. Zone of location of the blade defects depending on the distance from the blade lock

\begin{tabular}{|c|c|}
\hline Defect location zone & $\begin{array}{c}\text { Distance from the blade lock } H \text {, } \\
\mathrm{mm}\end{array}$ \\
\hline A & $0 \div 5,99$ \\
\hline B & $6 \div 12,99$ \\
\hline C & $13 \div 23,99$ \\
\hline D & $24 \div 43,99$ \\
\hline E & $44 \div 54,5$ \\
\hline
\end{tabular}

In a special station, model defects were made on the blades. The length of each of them was measured and assigned to a specific group (fig. 3).

The high cycle fatigue test was carried out using a testing machine - Brüel\&Kjær LDS V830 vibration exciter. A 30sample fatigue test was carried out to develop the Wöhler plot. The average value of the fatigue limit was determined on the basis of 15 samples. The method of increasing loads was applied. The tests assumed the basis of the fatigue test $N_{\mathrm{G}}=1 \cdot 10^{7}$ cycles and the initial stress amplitude $\sigma_{1}=363$ $\mathrm{MPa}$. The amplitude of the stress was increased by $\Delta \sigma=$ 29.4 MPa. Fatigue strength was determined under conditions of periodic sinusoidal stress [10].

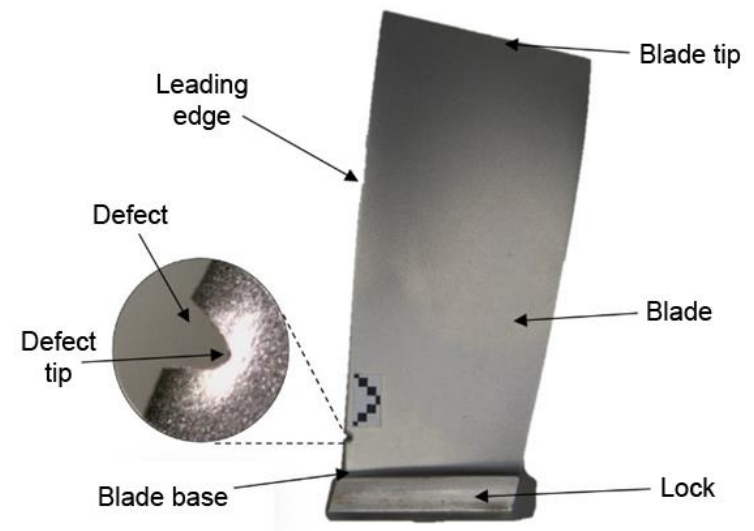

Fig. 3. Blade leading edge with defect in zone $A$; defect group $-V$

Methodology of non-destructive testing of blades after the fatigue test was developed. A non-destructive penetrantfluorescence method was adopted. The UVF-4 fluorescent penetrant, BRE-S cleaner, UVE fluorescent developer and ultraviolet light source were used.

The blades were washed ultrasonically in a solution of isopropyl alcohol (for degreasing) for $120 \mathrm{~s}$ and dried in compressed air. The UVF-4 penetrant was applied to the surface of the blade - its interaction time ranged from 5 to 6 min. The blade was then immersed in the BRE-S remover and dried with compressed air. A UVE developer was applied to the prepared surface of the blade.

\section{Research results and their analysis}

The fatigue test for the new, unpolluted vanes was the basis for the Wöhler plot illustrating the stress level $\sigma_{\mathrm{a}}$ as a function of the number of cycles to failure $N_{\mathrm{f}}$ (fig. 4) [11]. The fatigue strength of non-damaged blades $\sigma_{\mathrm{Z}}=563 \mathrm{MPa}$ was assumed as the main criterion in the assessment of the effect of the degree of damage on the fatigue strength of the blades. 


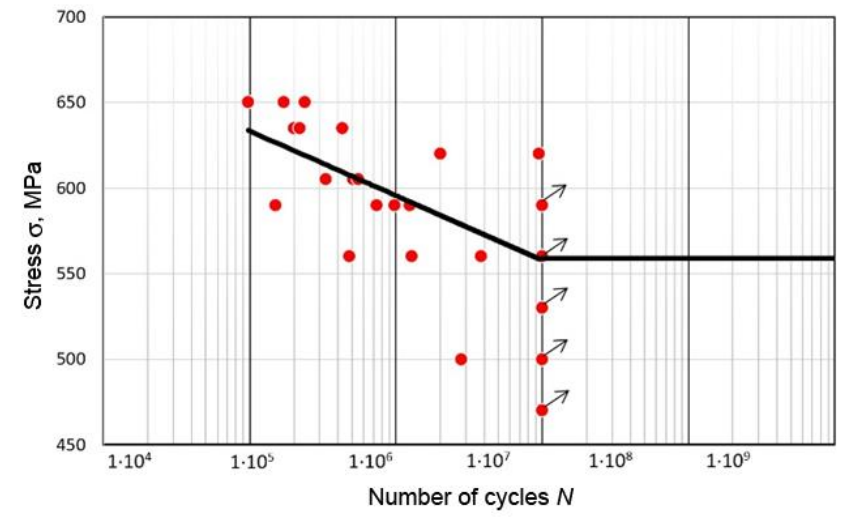

Fig. 4. Wöhler plot for the first stage vanes of an aircraft turbine compressor

TABLE III. Fatigue strength of damaged blades depending on the length and location of defects on the leading edge of the blade

\begin{tabular}{|c|c|c|c|c|c|c|c|}
\hline No. of blade & Defect group & $\begin{array}{l}\text { Defect location } \\
\text { zone }\end{array}$ & $\begin{array}{c}\text { Fatigue strength } \\
\sigma_{\mathrm{a}}, \mathrm{MPa}\end{array}$ & No. of blade & Defect group & $\begin{array}{c}\text { Defect location } \\
\text { zone }\end{array}$ & $\begin{array}{c}\text { Fatigue strength } \\
\sigma_{\mathrm{a}}, \mathrm{MPa}\end{array}$ \\
\hline L0059 & II & $E$ & 545 & L0113 & IV & $A$ & 305 \\
\hline L0060 & $\mathrm{I}$ & $E$ & 545 & L0114 & IV & $A$ & 305 \\
\hline L0061 & V & $E$ & 575 & L0115 & $\mathrm{V}$ & A & 305 \\
\hline L0062 & $\mathrm{VI}$ & $\mathrm{E}$ & 485 & L0116 & $\mathrm{V}$ & $\mathrm{A}$ & 275 \\
\hline L0063 & IV & $E$ & 545 & L0117 & $\mathrm{V}$ & $\mathrm{A}$ & 215 \\
\hline L0064 & VII & $E$ & 455 & L0118 & V & $A$ & 245 \\
\hline L0065 & VIII & $E$ & 455 & L0119 & $\mathrm{VI}$ & A & 215 \\
\hline L0066 & III & $E$ & 545 & L0120 & III & $\mathrm{C}$ & 215 \\
\hline L0067 & $\mathrm{I}$ & $\mathrm{D}$ & 575 & L0121 & IV & $\mathrm{C}$ & 395 \\
\hline L0068 & $\mathrm{I}$ & $\mathrm{D}$ & 575 & L0122 & 1 & $\mathrm{C}$ & 485 \\
\hline L0069 & I & $\mathrm{D}$ & 575 & L0123 & $\mathrm{I}$ & $\mathrm{C}$ & 485 \\
\hline L0070 & I & D & 455 & L0124 & I & C & 545 \\
\hline L0071 & II & $\mathrm{D}$ & 545 & L0125 & $\mathrm{I}$ & $\mathrm{C}$ & 485 \\
\hline L0072 & II & $\mathrm{A}$ & 455 & L0126 & II & $\mathrm{C}$ & 425 \\
\hline L0073 & II & $\mathrm{D}$ & 215 & L0127 & II & C & 425 \\
\hline L0074 & II & D & 365 & L0128 & IV & C & 305 \\
\hline L0075 & III & D & 455 & L0129 & IV & C & 275 \\
\hline L0076 & III & C & 245 & L0130 & III & $\mathrm{C}$ & 275 \\
\hline L0077 & III & D & 545 & L0131 & $\mathrm{V}$ & C & 215 \\
\hline L0078 & III & $D$ & 545 & L0132 & IV & $\mathrm{C}$ & 245 \\
\hline L0079 & IV & $\mathrm{D}$ & 545 & L0133 & II & $\mathrm{C}$ & 425 \\
\hline L0080 & IV & $\mathrm{D}$ & 515 & L0134 & II & C & 395 \\
\hline L0081 & IV & $\mathrm{D}$ & 575 & L0135 & III & $\mathrm{C}$ & 365 \\
\hline L0082 & IV & D & 545 & L0136 & III & C & 425 \\
\hline L0083 & $\mathrm{V}$ & $\mathrm{D}$ & 575 & L0137 & $\mathrm{I}$ & $B$ & 605 \\
\hline L0084 & $\mathrm{V}$ & $\mathrm{D}$ & 545 & L0138 & I & $B$ & 575 \\
\hline L0085 & V & D & 575 & L0139 & I & B & 515 \\
\hline L0086 & $\mathrm{V}$ & D & 545 & L0140 & 1 & B & 605 \\
\hline L0087 & VI & $\mathrm{D}$ & 545 & L0141 & II & $B$ & 485 \\
\hline L0088 & VI & D & 545 & L0142 & II & B & 515 \\
\hline L0089 & VI & D & 575 & L0143 & II & $B$ & 455 \\
\hline L0090 & $\mathrm{VI}$ & $\mathrm{D}$ & 545 & L0144 & II & $B$ & 485 \\
\hline L0091 & VII & $\mathrm{D}$ & 575 & L0145 & III & B & 335 \\
\hline L0092 & VII & D & 515 & L0146 & III & $B$ & 335 \\
\hline L0093 & VII & $\mathrm{D}$ & 575 & L0147 & III & $B$ & 395 \\
\hline L0094 & VII & $\mathrm{D}$ & 545 & L0148 & III & $B$ & 305 \\
\hline L0095 & VIII & D & 455 & L0149 & IV & $B$ & 245 \\
\hline L0096 & VIII & $D$ & 455 & L0150 & IV & $B$ & 305 \\
\hline L0097 & VIII & $\mathrm{D}$ & 455 & L0151 & IV & $B$ & 365 \\
\hline L0098 & VIII & D & 455 & L0152 & IV & $B$ & 365 \\
\hline L0099 & 1 & $\mathrm{~A}$ & 515 & L0153 & VII & $E$ & 575 \\
\hline L0100 & $I$ & A & 605 & L0154 & VIII & $E$ & 605 \\
\hline L0101 & II & A & 515 & L0170 & III & D & 545 \\
\hline L0102 & II & A & 485 & L0171 & III & D & 545 \\
\hline L0103 & $\mathrm{I}$ & A & 545 & L0172 & $\mathrm{V}$ & $\mathrm{D}$ & 575 \\
\hline L0104 & II & A & 515 & L0173 & V & D & 575 \\
\hline
\end{tabular}




\begin{tabular}{|c|c|c|c|c|c|c|c|}
\hline L0105 & II & $A$ & 515 & L0174 & VI & $A$ & 185 \\
\hline L0106 & 1 & $A$ & 605 & L0175 & VI & $A$ & 215 \\
\hline L0107 & III & $A$ & 455 & L0176 & $\mathrm{V}$ & $\mathrm{C}$ & 155 \\
\hline L0108 & III & $A$ & 455 & L0177 & $\mathrm{V}$ & C & 125 \\
\hline L0109 & III & $A$ & 425 & L0178 & VI & C & 95 \\
\hline L0110 & III & $A$ & 365 & L0179 & VI & C & 65 \\
\hline L0111 & IV & $A$ & 395 & L0180 & VI & $\mathrm{C}$ & 75 \\
\hline L0112 & IV & A & 395 & & & & \\
\hline
\end{tabular}

The fatigue strength of the blade, determined on the basis of the fatigue test, during which data on the stress value and the number of stress cycles was obtained (figs. 5 7 ), was used to determine the trend line (using the least squares method). The aim was to show the tendency to decrease the fatigue strength of the blade in the individual zones.

Analysis of the results of the fatigue test also allowed to determine the degree of impact of the damage - depending on its position on the leading edge in relation to the base of the pen (lock) - on the fatigue strength of the blade. The results of the fatigue test of fractures with defects of groups I-VIII were taken into account (fig. 7). It was found that defects lying within $24 \mathrm{~mm}$ from the base of the blade lock (zones $\mathrm{A}-\mathrm{C}$ ) have the greatest impact on reducing the fatigue strength of the blade.

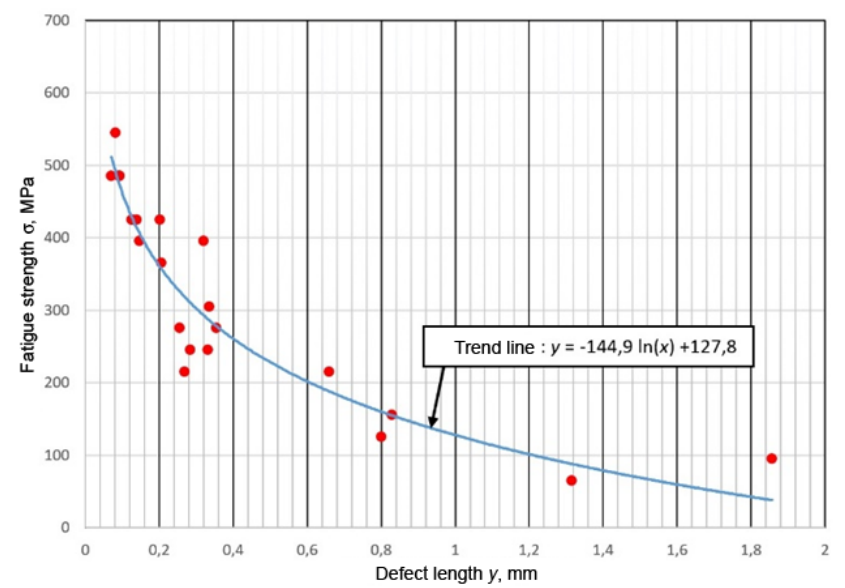

Fig. 5. Average fatigue strength of the blade as a function of defect length - zone C

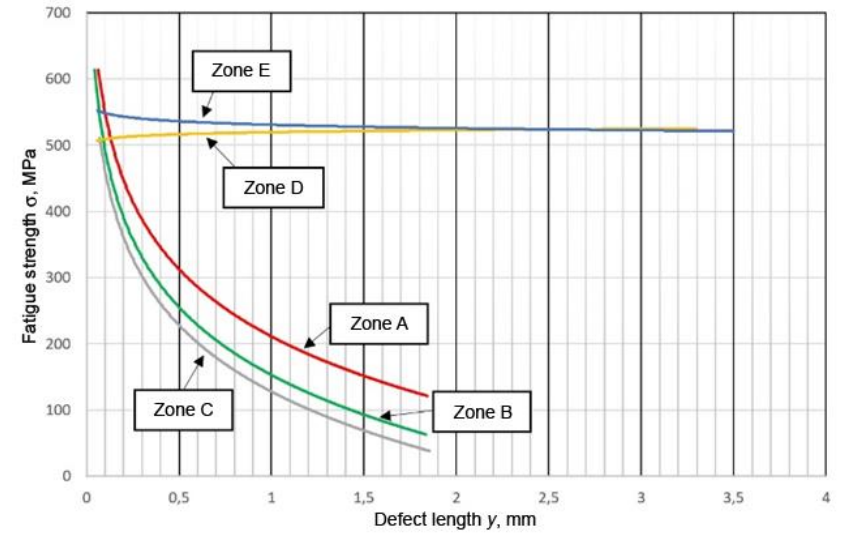

Fig. 6. Average fatigue strength of the blades depending on the length of defect - zone A-E

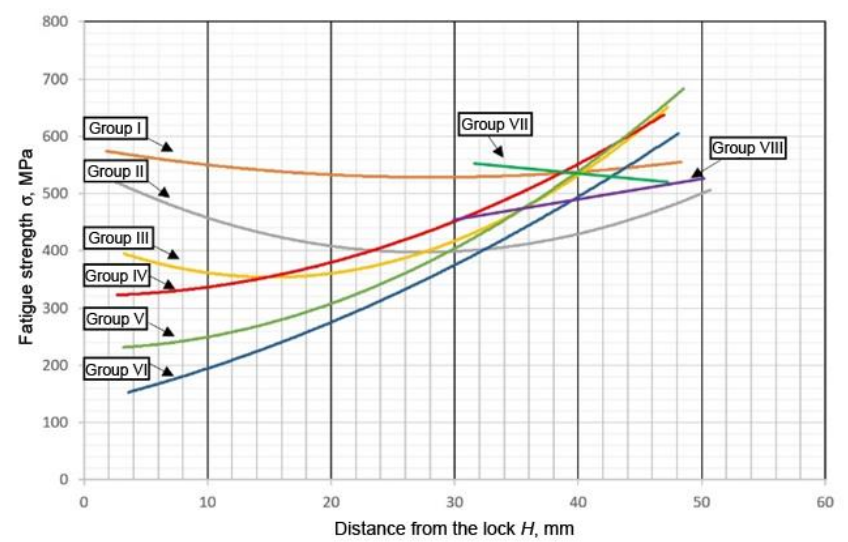

Fig. 7. Fatigue strength of the blades as a function of defect distance from the lock - defect group I-VIII

Macroscopic examinations using fluorescence method enabled observation of the source and nature of initiation and direction of fatigue cracks propagation of damaged blades. It was found that damaged blades after fatigue test are characterized by cracks between 6 and $14 \mathrm{~mm}$ long. Fatigue cracks most often are located on the upper (convex) surface of the blade. The direction of propagation of these cracks is parallel to the base of the blade lock (fig. 8) [12]

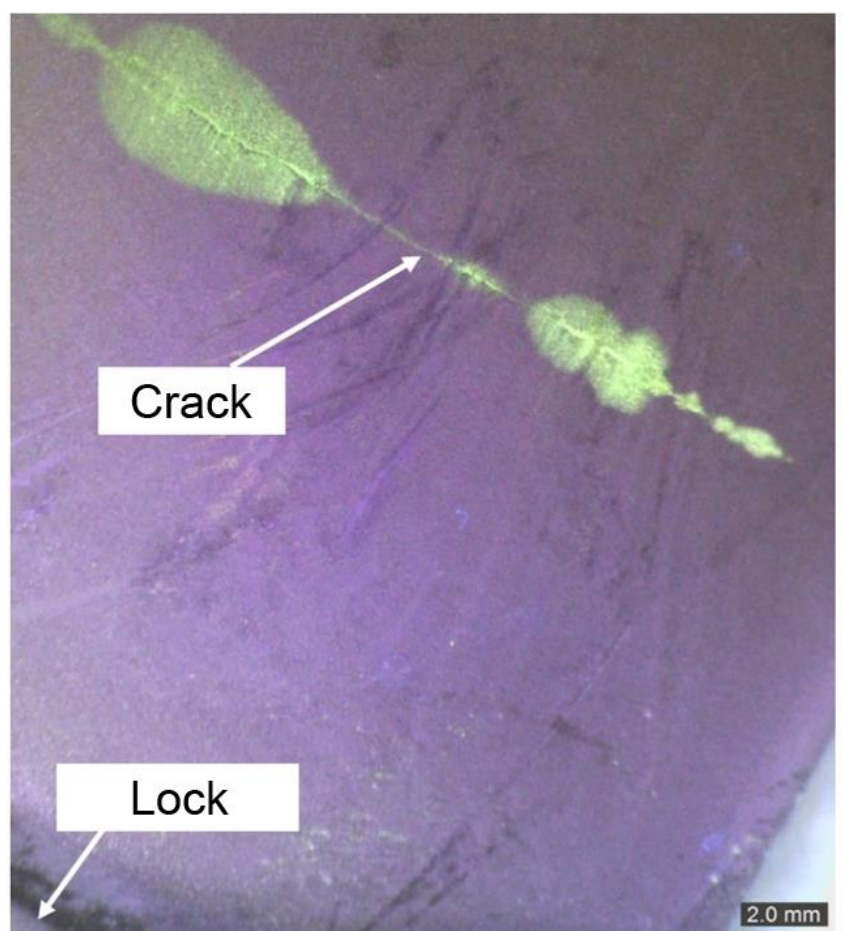

Fig. 8 The crack on the upper surface of the blade after a fatigue test

It was found that the sites of the crack initiation were usually found at the tip of the defect (fig. 3) - this was the case for all the blades after the fatigue test with defects in zones $\mathrm{B}$ and $\mathrm{C}$. At the same time it was found that cracks on the upper surface of the blade were initiated in its central part - this was characteristic for all blades after fatigue test with defects in zone $\mathrm{E}$ (tab. IV). The cracks formed in the 
central part of the blade ran at the distance from 5 to $12 \mathrm{~mm}$ from its lock.

TABLE IV. Fatigue cracks initiated at the tip of the blade defect depending on the position

\begin{tabular}{|c|c|}
\hline Damage zone & $\begin{array}{c}\text { Initiation of break } \\
\text { at the defect tip, \% }\end{array}$ \\
\hline A & 82 \\
\hline B & 100 \\
\hline C & 100 \\
\hline D & 42 \\
\hline E & 0 \\
\hline
\end{tabular}

\section{Conclusions}

Analysis of the test results allowed to determine that the length and location of the blade defects on its leading edge strongly, although to a different degree, affect its fatigue strength. It was found that the fatigue strength was most diminished in the case of blades with leading edge damage located within $24 \mathrm{~mm}$ from the base of the lock. Damage to the edge of the blade with a depth of $0.1 \mathrm{~mm}$, located in zones $A-C$, causes a marked decrease in fatigue strength. In turn, damage located at a distance $>24 \mathrm{~mm}$ from the base of the lock has little or no effect on the fatigue strength of the blades.

It has been shown that the smallest fatigue strength is characteristic for blades with defects on leading edge located at a distance of 13 to $24 \mathrm{~mm}$ from the lock. For example, damage with a length of $1.3 \mathrm{~mm}$ reduces the fatigue strength to $65 \mathrm{MPa}$.

Macroscopic examinations after the fatigue test of the blades with defects on the leading edge located at a distance of less than $24 \mathrm{~mm}$ from the lock indicate a tendency to initiate fatigue cracks on the upper surface of the blade at the tip of the defect. The propagation direction of the cracks is perpendicular to the leading edge of the blade.

The presented work was carried out as part of the Lider project (No. LIDER/002/039/L-5/13/NCBiR/2014, entitled "Image analysis in the classification of damage to aircraft engine compressor blades and forecasting their life"), financed by National Centre for Research and Development.

\section{REFERENCES}

1. Chen X., Hutchinson J.W. "Particle impact on metal substrates with application to foreign object damage to aircraft engines". Journal of the Mechanics and Physics of Solids. 50, 12 (2002): pp. 2669-2690.

2. Shabaycovitch $\mathrm{V}$. "Competitiveness of products, equipment and technological processes in machine-building". Advances in Manufacturing Science and Technology. 36, 1 (2012): pp. 73-80.

3. Kowalewski Z.L. „Zmęczenie materiałów - podstawy, kierunki badań, ocena stanu uszkodzenia”. Materiały XVII Seminarium „Nieniszczące Badania Materiałów”, Zakopane 2011.

4. Kozakiewicz A. „Analiza uszkodzeń turbinowych silników odrzutowych”. Prace Instytutu Lotnictwa. 213, 22 (2011): pp. 224234.

5. Wyrzykowski W.J., Pleszakow E., Sieniawski J. „Odkształcenie i pękanie metali". Warszawa: WNT, 1999.

6. Witek L. "Vibration analysis for detecting failure of compressor blade". Engineering Failure Analysis. 25, 1 (2012): pp. 211218.

7. Sieniawski J. „Kryteria i sposoby oceny materiałów na elementy lotniczych silników turbinowych". Rzeszów: Oficyna Wydawnicza Politechniki Rzeszowskiej, 1995.

8. Witek $L$. "Experimental crack propagation and failure analysis of the first stage compressor blade subjected to vibration". Engineering Failure Analysis. 16, 7 (2009): pp. 21632170.
9. Masłyk M., Obrocki W., Setkowicz A., Sieniawski J. "Experimental fatigue strength determination of damaged aircraft engine blades". Advances in Manufacturing Science and Technology. 40, 4 (2016): pp. 55-65.

10. Zakrzewski M., Zawadzki J. „Wytrzymałość materiałów”. Warszawa: PWN, 1983

11. PN-76/H-04325:1976 Badanie metali na zmęczenie. Pojęcia podstawowe i ogólne wytyczne przygotowania próbek oraz przeprowadzania prób.

12. Nikhamkin N. "Crack propagation in turbojet blades. Experimental technique and results". International Journal of Fatigue. 18, 8 (1996): pp. 604-610

Translation of scientific articles, their computer composition and publishing them on the website www.mechanik.media.pl by original articles in Polish is a task financed from the funds of the Ministry of Science and Higher Education designated for dissemination of science.

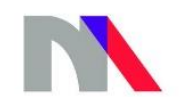

Ministry of Science and Higher Education

Republic of Poland 